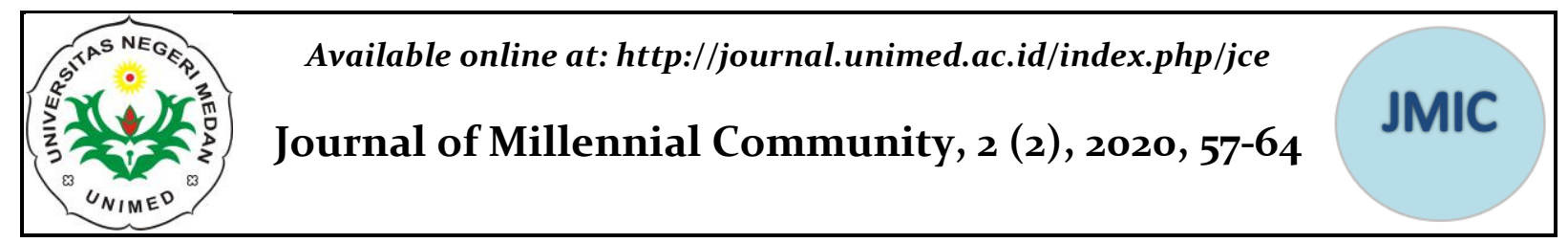

\title{
Kebermaknaan Perubahan Dalam Kepemimpinan Administrator Badan Pengembangan Sumber Daya Manusia
}

\author{
Herita Dewi \\ Widyaiswara Ahli Madya BPSDM Provinsi Sumatera Barat \\ Email: tundewi69@gmail.com
}

\begin{abstract}
Abstrak
Artikel ini bertujuan untuk mendeskripsikan pentingnya arti perubahan dalam kepemimpinan untuk mendorong dan mempengaruhi perubahan kinerja organisasi yang berkinerja tinggi. Menggunakan metode pengumpulan dan analisis data melalui stock opname dari berbagai buku teks, jurnal dan dokumen. Makalah ini diharapkan dapat memberikan gambaran tentang bagaimana peran kepemimpinan (administrator) mampu mendorong perubahan pada organisasi yang berkinerja tinggi. Makna tersebut setidaknya dapat dilihat dari tiga domain yaitu kepemimpinan, makna perubahan itu sendiri, dan cara Mendorong terjadinya perubahan dalam organisasi dan mampu meningkatkan kapasitas untuk merencanakan, melaksanakan, mengelola konflik yang terjadi sebagai akibat dari perubahan, dan memastikan perubahan tersebut berjalan sesuai harapan. Untuk meningkatkan kualitas sektor publik diperlukan birokrasi yang visioner, berkarakter, dan mampu memimpin transformasi sektor publik.
\end{abstract}

Kata Kunci: Kepemimpinan, Arti Perubahan dan Kinerja Organisasi

\section{The Significance of Changes in the Leadership of Human Resources Development Board Administrators}

\begin{abstract}
This paper aims to describe the importance of the meaning of change in leadership in order to encourage and influence changes in the performance of high-performing organizations. Using data collection and analysis methods through stock-taking from various textbooks, journals and documents. This paper is expected to provide an overview of how the role of leadership (administrator) is able to drive changes in highperformance organizations. This meaningfulness can be seen from at least three domains namely leadership, the meaning of change itself, and how to encourage change to occur in the organization and be able to increase the capacity to plan, implement, manage conflicts that occur as a result of change, and ensure the change goes according to expectations. To improve the quality of the public sector we need a bureaucracy that is visionary, has character, and is able to lead public sector transformation.
\end{abstract}

Keywords: Leadership, Meaning of Change and Organizational Performance

\section{PENDAHULUAN}

Mengacu pada Pasal 52 ayat (2) huruf a Peraturan Pemerintah Nomor 17 Tahun 2020 tentang Manajemen Pegawai Negeri Sipil, pejabat administrator harus menjamin akuntabilitas jabatannya untuk memimpin pelaksanaan seluruh kegiatan yang sudah direncanakan dengan baik dan efisien sesuai standar operasional prosedur dan terselenggaranya peningkatan kinerja secara berkesinambungan. Sudah menjadi tuntutan 
dan kebutuhan pejabat administrator memiliki tanggung jawab memimpin pelaksanaan seluruh kegiatan pelayanan publik serta administrasi pemerintahan dan pembangunan bagi keberlangsungan (survive) unit organisasi, yaitu dalam peningkatan kinerja unit organisasi yang dilakukan oleh anggotanya seperti pejabat pengawas dan pejabat pelaksana dalam memberikan pelayanan publik.

Pelayanan publik yang dikelola dan dikendalikan dengan baik, merupakan bagian yang tidak terpisahkan dari peningkatan kualitas kinerja unit organisasi. Sosok pejabat administrator yang dapat memainkan peran tersebut adalah pejabat yang telah memenuhi kriteria kepemimpinan manajemen kinerja, sehingga cepat atau lambatnya peningkatan kinerja organisasi akan ditentukan oleh kualitas manajemen kinerja yang dilakukan oleh para pejabat administrator.

Merujuk kepada sistem manajemen kepegawaian, pejabat adminstrator memainkan perananan yang sangat menentukan dalam menjabarkan apa yang dituju oleh instansi ke dalam programprogram dan memimpin bawahan dan seluruh stakeholder strategis untuk melaksanakan program-program tersebut secara efektif dan efisien. Tugas ini menuntutnya memiliki kemampuan kepemimpinan taktikal yaitu kemampuan dalam menjabarkan tujuan instansi ke dalam program instansi dan kemampuan menyesuaikan dan beradaptasi terhadap perubahan lingkungan yang begitu dasyat termasuk stakeholder lainnya yang akan berpengaruh terhadap makna perubahan itu sendiri.

Untuk mengembangkan kompetensi pejabat administrator dalam rangka memenuhi standar kompetensi manajerial jabatan administrator, dapat diwujudkan melalui pelatihan kepemimpinan administrator yang merupakan bentuk pelatihan struktural kepemimpinan administrator sebagaimana diamanatkan berdasarkan ketentuan Pasal 217 ayat (5) Peraturan Pemerintah Nomor 17 Tahun 2020 tentang Manajemen Pegawai Negeri Sipil.
Sebagai pejabat struktural, pejabat administrator harus memiliki kompetensi manajerial yang dibutuhkan dalam rangka penyelenggaraan pemerintahan.

Mengkaji fakta selama ini pejabat adminstrator lebih hanya sekedar ritual yang Page $\mid 58$ lazim dilaksanakan pada tataran pejabat administrator. Konteks ritual ini dapat ditinjau dari perspektif penyelenggara dan peserta diklat. Kebanyakan mereka kesulitan dalam mengidentifikasi/mendioagnosa, menggagas ide-ide, sampai kepada membuat dan melaksanakan suatu perubahan /inovasi, (Evaluasi penyelenggaraan Diklat Dewi, Herita ; 2019) Ini tentunya bertentangan dengan yang idealnya, dimana peserta dituntut untuk menunjukkan kinerjanya dalam merancang dan menginisiasi suatu perubahan di unit kerjanya, memimpin perubahan tersebut hingga menimbulkan hasil yang signifikan bagi organisasinya. Kemampuan memimpin perubahan inilah yang kemudian menentukan keberhasilan peserta tersebut dalam memperoleh kompetensi yang ingin dibangun dalam penyelenggaraan pelatihan kepemimpinan

Dengan demikian, Pelatihan Kepemimpinan Administrator akan dapat menghasilkan alumni yang tidak hanya memiliki kompetensi, tetapi juga mampu menunjukkan kinerjanya dalam memimpin perubahan, yang berdampak sangat berarti terhadap kinerja organisasi dan mempunyai keberlanjutan jangka panjang.

\section{PEMBAHASAN}

1. Kepemimpinan dalam Pelayanan Publik

Guna mencapai tujuan pembangunan nasional, sampai saat sekarang tidak dapat kita pungkiri bahwa lingkungan pemerintahan atau birokrasi masih memegang peran yang sangat penting bahkan sangat urgent/menentukan. Untuk itu posisi seperti ini dibutuhkan pemimpin kinerja yang mampu memberikan pelayanan publik secara professional dan berkualitas. Hal ini tidak mudah untuk dilaksanakan butuh berbagai pemikiran dan perubahan mindset bagaimana menjadi pelayan yang 
baik bagi masyarakat. Joseph C. Rost berpendapat bahwa kepemimpinan adalah hubungan yang saling mempengaruhi diantara pemimpin dan pengikut (bawahan) yang menginginkan perubahan nyata dan mencerminkan tujuan yang sama.

Secara umum kepemimpinan adalah suatu kewenangan yang disertai kemampuan seseorang dalam mamberikan pelayanan untuk menggerakkan orang-orang yang berada di bawah koordinasinya dalam usaha mencapai tujuan. Pemimpin adalah seseorang yang mempunyai kemampuan dalam penyelenggaraan suatu kegiatan organisasi agar kegiatan tersebut dapat terselenggara dengan efisien daan efektif serta bermanfaat. Untuk itu diperlukan diperlukan pengaturan mengenai tugas, cara kerja dan hubungan antara pekerjaan yang satu daengan pekerjaan yang lain agar terjadi ketertiban dala kegiatan organisasi.

Secara umum kepemimpinan adalah suatu kewenanga yang disertai kemampuan seseorang dalam mamberikan pelayanan untuk menggerakan orang-orang yang berada dibawah koordinasinya dalam usaha mencapai tujuan. Pemimpin adalah seseorang yang mempunyai kemampuan dalam penyelenggaraan suatu kegiatan organisasi agar kegiatan tersebut dapat terselenggara dengan efissien daan esfektif serta bermanfaat. Untuk itu diperlukan diperlukan pengaturan mengenai tugas, cara kerja dan hubungan antara pekerjaan yang satu daengan pekerjaan yang lain agar terjadi ketertiban dala kegiatan organisasi. Dari uraian diatas dapat dimaknai bahwa memimpin adalah kemampuan seseorang untuk mengilhami bawahan agar dapat bekerja untuk mencapai tujuan organisasi. Dengan demikian, pemimpin akan sukses jika:

a. Pemimpin mempunyai kemampuan untuk memaklumi pandangan orang lain.

b. Pemimpin harus peka tehadap massalah orang lain.

c. Pemimpin harus tanggap terhadap apa yang dikatakan bawahan. a. Pemimpin harus mempunyai kemampuan analisin yang tinggi.

b. Pemimpin harus mengetahui kelebihan atau kelemahan dan kesalahanya

c. Pemimpin harus berseedia menerima tanggung jawabnya .

Untuk memperbaiki kualitas pelayaan sektor publik diperlukan adanya kepemimpinan birokrasi yang visioner, berkarakter, dan mampu memimpin trasnformasi perubahan sektor publik. Organisasi publik yang inovatif dan berkinerja tinggi biasanya dipengaruhi oleh kualitas kepemimpinannya. Ilustrasi kekuasaan ada pada pimpinan. Dalam budaya paternalistik posisi pemimpin sangat strategis karena konsen penguatan kapasitas kepemimpinan memiliki efek yang sangat besar terhadap kualitas penyelenggaraan pemerintahan. Upaya untuk membentuk kepimpinan di birokrasi pemerintahan dianggap belum optimal. Investasi pada hal ini masih sangat kecil baik dari aspek kebijakan, program dan kegiatan, sumberdaya.

Dalam rangka mengantisipasi berbagai permasalahan tersebut diperlukan adanya suatu program dan kegiatan untuk para pemimpin aparatur pengelola pelayanan publik sehingga mampu meningkatkan kapasitas merencanakan, melaksanakan, mengelola konflik yang terjadi sebagai akibat perubahan, dan memastikan perubahan berjalan sesuai dengan ekspektasinya. Untuk memperbaiki kualitas sektor publik diperlukan adanya kepemimpinan birokrasi yang visioner, berkarakter, dan mampu memimpin trasnformasi sektor publik. Organisasi publik yang inovatif dan berkinerja tinggi biasanya dipengaruhi oleh kualitas kepemimpinannya. Untuk memperkuat kepemimpinan juga sanagat dipengaruhi oleh berbagai nutrisi yang masuk, diantaranya adalah pendikakan dan pelatihan yang sudah dilalui.

2. Peran Pemimpin dalam Pelayanan Publik

Berdasarkan konsep teoretis, pemimpin memiliki tanggung jawab yang besar dalam suatu organisasi karena 
kepemimpinan adalah inti dari manajemen yang merupakan penggerak bagi sumber dan fungsi manajemen serta alat lainnya. Dengan demikian peran pemimpin sangat penting dalam mencapai tujuan suatu organisasi, sehingga keberhasilan dan kegagalan dalam organisasi ditentukan oleh kualitas kepemimpinan.

Ditinjau dari tingkatan pemimpin, maka pemimpin terdiri atas:

1. Pemimpin tingkat atas /

(top management)

2. Pemimpin menengah/adminstrator management)

3. Pemimpin tingkat bawah/pengawas (lower management)

Salah satu peranan pemimpin dalam meningkatkan pelayanan publik adalah pemotivasian bawahan. Tinggi rendahnya motivasi kerja pegawai dipengaruhi beberapa faktor diantaranya lingkungan tempat bekerja. Maka pemimpin harus menciptakan suasana harmonis yang dapat mendorong atau menimbulkan motivasi kerja yang tinggi. Lingkungan yang dapat menimbulkan motivasi kerja pegawai adalah hubungan antara atasan dengan bawahan (hubungan vertikal) dan hubungan antara sesama bawahan (hubungan horizontal). Jika kedua hubungan tersebut terjalin dengan baik, maka produktivitas kerja para pegawai akan lebih tinggi dan sebaliknya.

Selanjutnya peran pemimpin ialah mencapai efisiensi dengan produktivitas yang tinggi. Efisiensi dan produktivitas yang tinggi dapat dicapai jika pemimpin berperan secara efektif dalam mengkoordinasikan semua bawahan dilingkungannya. Pemimpin harus memberikan pelayanan yang baik kepada bawahan dan lingkungan, melalui kebijakan maupun pelayanan yang baik agar tujuan organisasi dapat terselenggara atau tercapai.

3. Makna Perubahan.

Dalam tulisan ini, yang disasar adalah makna perubahan yang inovatif yang merupakan terobosan untuk mencapai kemajuan dan kinerja yang lebih baik (better performance) dan bermanfaat bagi organisasi/unit organisasi sektor publik yang pada akhirnya dapat memberikan kontribusi bagi kemajuan daerah.

Kemajuan teknologi informasi yang Page $\mid 60$ melampaui batas-batas wilayah negara telah mengubah dan mempengaruhi peradaban manusia , seperti kegiatan ekonomi, bisnis, pendidikan, sosial budaya, politik dan perilaku masyarakat. Semua inovasi tersebut diharapkan membuat aktivitas dan kehidupan makin mudah, efisien dan efektif.

Instansi pemerintah baik pada level nasional sampai daerah juga terdampak perkembangan lingkungan strategis. Jika ingin tetap eksis dan memiliki peran strategis bagi kemajuan bangsa dan negara Indonesia, maka setiap instansi /lembaga harus senantiasa melalukan perubahan (continous improvement) sekecil apapun sepanjang sesuai peraturan, dengan tujuan meningkatkan kinerja atau mencapai kinerja yang lebih baik (better perfomance) dalam rangka membangun birokrasi yang lebih efisien, efektif dan mampu mendorong kemajuan. (budi : 2019)

Untuk mencapai kondisi atau kinerja yang tinggi, diperlukan perubahan dan proses perubahan tersebut harus dilakukan dengan baik dengan menerapkan inovasiinovasi yang dapat mempercepat pencapaian kinerja secara siginifikan. Misalnya, pelayanan publik yang semula manual, menjadi $e$ - service dengan dukungan sistem dan prosedur yang lebih baik, jelas dan terukur dan sumber daya manusia yang kompeten, serta penerapan teknologi informasi. Hasilnya, pelayanan yang semula rumit, lama dengan biaya yang kurang jelas, menjadi lebih sederhana, cepat, dan biaya pasti. Contoh lain, pengelolaan aset (barang milik negara/daerah) yang semula dilakukan secara parsial dan sebagian manual sehingga sulit mengetahui data aset yang benar (jumlah, kondisi, status dan lokasinya) diubah dengan sistem yang komprehensif dan teknologi informasi yang tepat, sehingga menghasilkan data aset yang dapat dengan 
cepat diketahui dan akurat (jumlah, kondisi, lokasi, statusnya).

Perubahan dan inovasi tidak dapat dipisahkan, bagaikan dua sisi dari mata uang. Dalam konteks ini, perubahan dimaksudkan adalah perubahan yang mengandung inovasi yang relevan, sesuai dengan tuntutan organisasi. Terminologi yang tepat untuk hal ini, kita sebut sebagai perubahan inovatif, atau perubahan yang inovatif. Maknanya, perubahan tersebut mengandung sesuatu yang baru, yang dapat membawa kemajuan dan manfaat yang signifikan bagi peningkatan kinerja organisasi, instansi dan individunya (pimpinan dan staf). Inovasi membawa perubahan, tetapi perubahan tidak selalu karena dan mengandung inovasi. Perubahan yang tidak inovatif dapat dinilai sebagai perubahan yang tidak berdampak besar pada peningkatan kinerja

Komitmen terhadap perubahan akan lebih besar jika mereka yang dipengaruhi oleh perubahan tersebut diizinkan untuk serta sebanyak mungkin dalam perencanaan dan pelaksanaannya. Sasarannya adalah membuat mereka memiliki perubahan sebagai sesuatu yang mereka inginkan dan senang untuk hidup dengannya. Untuk memperoleh komitmen terhadap perubahan meru- pakan bagian penting dari sebuah program manajemen perubahan. Tanggung jawab terhadap pengelolaan perubahan harus mempertimbangkan perasaan dan emosi orang-orang yang terlibat di dalamnya. jika hal ini diabaikan atau tim manajemen perubahan tidak sensitif terhadap hal ini, maka perubahan tidak akan dapat terjadi sesuai rencana yang telah dibuat.

Bagi Administrator, sebagai pimpinan di tingkat menengah dalam birokrasi, yang bertanggung jawab memimpin pelaksanaan seluruh kegiatan pelayanan publik serta administrasi pemerintahan dan pembangunan di unit organisasinya, juga memiliki tantangan untuk mampu menghasilkan kinerja terbaiknya. Untuk itu, perbaikan atau perubahan berkelanjutan yang inovatif menjadi suatu kebutuhan, apalagi perkembangan lingkungan eksternal saat ini sangat cepat dipicu dengan berbagai temuan inovatif utamanya di bidang teknologi informasi.

Jadi pada makna yang sesungguhnya Page 61 dalam proses perubahan seorang pemimpin harus berupaya untuk ikut melatih perubahan pada dirinya sendiri sehingga terjadi suatu integritas pada dirinya dan perubahan ini akan mempengaruhi terjadinya perubahan kinerja dalam organisasi yang dipimpinnya. Pemimpin mempunyai peran untuk bertanggungjawab menyiapkan calon pemimpin dan membentuk pemimpin perubahan.

4. Pengembangan Inovasi.

Upaya untuk mencapai kondisi yang lebih baik adalah suatu keniscayaan. Perubahan dan tuntutan yang terjadi di lingkungan strategis harus diantisipasi secepat dan sebaik mungkin. Jika tidak, ia akan tidak berarti dan tidak dapat berperan dalam kehidupan di lingkungannya. Upaya atau proses untuk mencapai kondisi yang lebih baik, mengandung arti perlu adanya perubahan. Idealnya, perubahan harus diusahakan, direncanakan dan dilaksanakan dan bukan ditunggu kapan datangnya. Biasanya, perubahan terjadi karena ada suatu temuan, baik yang disengaja ataupun tidak disengaja, yang mendorong perubahan-perubahan lainnya. Temuan tersebut dapat disebut sebagai inovasi, yaitu sesuatu yang belum ada sebelumnya paling tidak di suatu lingkungan masyarakat, menjadi ada, disediakan atau diterapkan.

Temuan menimbulkan perubahan dan tuntutan lingkungan baik pada saat itu maupun perkiraan perubahan lanjutan pada di masa datang. Untuk itu, perubahan organisasi/unit organisasi perlu dilakukan untuk secepatnya, mengantisipasi tuntutan tersebut. Penemuan baru atau Inovasi utamanya bidang teknologi mendorong perubahan. Inovasi di sektor publik adalah salah satu jalan atau bahkan breakthrough untuk mengatasi kemacetan dan kebuntuan organisasi di sektor publik. Karakteristik dari sistem di sektor publik yang rigid, kaku dan 
cenderung status quo harus bisa dicairkan melalui penularan budaya inovasi yang inovatif

Hal ini tidak terlepas dari dinamika eksternal dan tuntutan perubahan yang sedemikian dahsyat yang terjadi di luar organisasi, di samping perubahan di masyarakat dengan tingkat literasi yang lebih baik, mempunyai kesadaran (awareness) yang lebih baik akan haknya. Dengan demikian maka sektor publik dapat menjadi sektor yang dapat mengakomodasi dan merespons secara cepat setiap perubahan yang terjad dan makna dari perubahan itu sendiri.

Dalam hal inovasi di sektor publik, pemerintah mempunyai 3 (tiga) peranan dalam menginovasi kebi- jakan, yaitu: (a) Policy innovation: new policy di- rection and initiatives (inovasi kebijakan). (b) Innovation in the policy making process (inovasi dalam proses pembuatan kebijakan). (c) Policy to foster in- novation and its diffusion (kebijakan untuk mengem- bangkan inovasi dan penyebarannya)

\section{Mengelola Perubahan Organisasi}

Apabila dilihat secara makro dalam mengelola perubahan organisasi perlu terlebih dahulu memahami manajemen perubahan dengan strategi perubahan dan tahapan manajemen perubahan yang meliputi empat tahapan yang dapat yakni :

a. Memahami Permasalahan: Diagnosa Organisasi

Diagnosa ini merupakan tahap awal, dan yang paling menentukan dalam suatu organisasi untuk melakukan perubahan secara tepat mencapai organisasi berkinerja tinggi (OBT). Cara yang paling tepat dalam memahami permasalahan dengan menganalisa pemasalahan yang ada dalam organisasi/unit organisasi, melakukan penilaian terhadap kondisi fungsi-fungsi organisasi sesuai dengan jenjang jabatannya dalam rangka merancang perubahan secara tepat. Aktivitas analisa ini dikenal sebagai diagnosa organisasi: organizational diagnosis, involves diagnosing or assessing an organization's current level of functioning in order to design appropriate change interventions) (dalam Sunari, LAN, 2014). Fungsi-fungsi atau bagian-bagian organisasi mana saja yang bermasalah, sebagai acuan untuk untuk merumuskan upaya perbaikan yang tepat. Untuk tingkat ASN Administrator, fungsi-fungsi atau bagianbagian yang bermasalah dibatasi sesuai tingkat unit organisasi tempatnya bekerja.

Ini masih secara makro, karena untuk merumuskan atau mendisain upaya perubahan yang tepat (to design appropriate interventions), kita tidak dapat hanya melihat kondisi saat ini saja, tetapi juga mengetahui kondisi apa yang ingin dicapai, yang ideal atau yang diharapkan. Karena itu, untuk itu, lebih memperjelas, diagnosa organisasi dapat kita artikan sebagai upaya menganalisa atau menilai kondisi atau tingkat kinerja fungsi-fungsi (elemen, unsur) organisasi saat ini dalam rangka memahami permasalahan, dan menyusun rencana perubahan untuk mencapaikan kondisi atau kinerja yang diinginkan. Dengan mengetahui kondisi saat ini atau permasalahan yang ada dan kondisi yang akan dicapai, maka kita dapat menilai seberapa serius gap yang terjadi dan apa rumusan solusi inovatif yang tepat.

Aktivitas mendiagnosa harus dilakukan sungguh-sungguh dengan tujuan menemukan permasalahan yang akan diubah. Mendiagnosa dilakukan dengan membaca, melihat, menilai yang dilandasi dengan, niat atau tujuan untuk mengetahui secara mendalam tentang permasalahan organisasi dan merumuskan solusinya untuk mencapai kondisi yang diharapkan. Hal ini dapat dilakukan dengan pengamatan, dengan pengisian kuesioner, dan wawancara mendalam. Untuk menghasilkan analisa yang tajam, kita dapat melakukan ketiganya dalam suatu aktivitas diagnosa yang sama.

\section{b. Merencanakan Perubahan}

Perencanaan perubahan dituangkan dalam rencana secara komprehensif yang disampaikan kepada para pihak terkait baik internal maupun eksternal, yang utamanya para pihak dalam organisasi/unit organisasi terkait. 
c. Melaksanakan Rencana Perubahan

Setelah rencana perubahan disusun rinci, ditetapkan, disosialisasikan, maka tahap berikutnya adalah melaksanakannya. Pelaksanaan dilakukan secara konsisten mengacu pada jadwal dan urutan kegiatankegiatannya. Strategi perubahan yang dapat digunakan dapat mengacu pada tabel keterkaitan strategi perubahan dan manajemen perubahan, atau dari sumber lain.

Untuk menjamin terlaksananya kegiatan-kegiatan perubahan dan pencapaian target sesuai rencana, perlu dilakukan upaya pengendalian sepanjang pelaksanaan rencana perubahan. Pengertian pengendalian adalah kegiatan pemantauan ditambah tindak lanjut perbaikan jika dijumpai ada hal yang kurang atau tidak tepat pada saat pelaksanaan

d. Mengevaluasi Hasil Pelaksanaan Perubahan

Diperlukan data lengkap untuk melakukan evaluasi, oleh karena itu dalam tahap ini dilakukan pengumpulan data untuk evaluasi. Sumber data utama adalah hasil pengendalian (pemantauan ditambah tindak lanjut) yang dilaksanakan secara berkala sepanjang pelaksanaan rencana perubahan. Evaluasi dilakukan dengan membandingkan capaian pada akhir pelaksanaan perubahan dengan rencana perubahan.

\section{SIMPULAN}

Bagi Administrator, sebagai pimpinan di tingkat menengah dalam birokrasi, yang bertanggung jawab memimpin pelaksanaan seluruh kegiatan pelayanan publik serta administrasi pemerintahan dan pembangunan di unit organisasinya, juga memiliki tantangan untuk mampu menghasilkan kinerja terbaiknya. Untuk itu, perbaikan atau perubahan berkelanjutan yang inovatif menjadi suatu kebutuhan, apalagi perkembangan lingkungan eksternal saat ini sangat cepat dipicu dengan berbagai temuan inovatif utamanya di bidang teknologi informasi

\section{DAFTAR PUSTAKA}

Anoraga, P. (2003). Psikologi Kepemimpinan (Keempat ed.). Jakarta, DKI Jakarta: PT. Rineka Cipta.

Arikunto, S. (2009). Evaluasi Program Pendidikan: Pedoman Teoritis Praktis Bagi Mahasiswa dan Praktisi Pendidikan. Jakarta, DKI Jakarta: Bumi Aksara.

Dewi, Herita (2019), Evaluasi Penyelenggaraan Diklat Kepemimpinan Tk III. Padang, Jurnal Edukasi

Ismail, et.al. , 2010. Menuju Pelayanan Prima, Konsep dan Strategi Peningkatan Kualitas Pelayanan Publik, Averroes Press, Malang.

Nugroho, R. (2011). Public Policy Dinamika Kebijakan - Analisis Kebijakan Manajemen Kebijakan (ketiga ed.). Jakarta, Jakarta, Jakarta: PT. Elex Media Komputindo.

Kartini Kartono, Pemimpin dan Kepemimpinan, Apakah Kepemimpinan Abnormal itu?

PT. Raja Grafindo Persada, Jakarta.

Siagian, S. P. (1988). Organisasi kepemimpinan dan perilaku administrasi (Kelima ed.). Jakarta, DKI Jakarta: Haji Masagung.

Slamet, $\quad$ M. $\quad(2014, \quad 12 \quad 11)$. http://daerah.sindonews.com/read/935 996/22/ini-19-kepala-daerahberprestasi-dan- inovatif-1418288038/1. Retrieved 03 16, 2016, from http://daerah.sindonews.com:http://d aerah. sindonews.com

Tayibnapis, F. Y. (2000). Evaluasi Program. Jakarta, DKI Jakarta: Rineka Cipta. 
Journal of Millennial Community, 2 (2), September 2020

Herita Dewi

\section{PROFIL SINGKAT}

Ulum, M. Chazienul. (2012). Leadership: Dinamika Teori Pendekatan dan Isu Strategis Kepemimpinan di Sektor Publik. Tim UB Press.
Penulis Herita Dewi, merupakan Widyiswara Ahli Madya pada Badan Pengembangan Sumber Daya Manusia Provinsi Sumatera Barat, Indonesia. 